\title{
ACCEPTABILITY AND NUTRIENTS CONTENT (VITAMIN B12 AND FOLIC ACID) OF SUBTITUTED SNACK BAR WITH PURPLE SWEET POTATO (IPOMOEA BATATAS L.) ENRICHED WITH NUTRITIONAL YEAST AS HEALTHY VEGAN FOOD
}

\author{
Achmad Maralda Ainin Ghifari ${ }^{{ }^{*}}$ \\ ${ }^{1}$ Nutrition Undergraduate Program, Faculty of Public Health, Universitas Airlangga, Surabaya, Indonesia \\ *E-mail: achmad.maralda.ainin-2015@fkm.unair.ac.id
}

\begin{abstract}
Vegan are group of people who have high risk of megaloblastic anaemia because of vitamin B12 and folic acid deficiency. Purple sweet potato (Ipomoea Batatas L.) and nutritional yeast are rich vitamin B12 and folic acid, therefore can be formulated into healthy food, such as snack bar for vegan. The purpose of this study is to determine the effect of purple sweet potato substitution and nutritional yeast addition on acceptability and availability of vitamin B12 and folic acid of snack bar. The type of research of formulation was true experimental design (Complete Randomize Design) with 1 formula control and 2 modified formula. This research was carried out for 3 months (December 2018-March 2019) in Nutrition Laboratory Universitas Airlangga. The panelists are 38 people who affiliated with vegan community Yayasan Buddha Maitreya Surabaya. Statistical analysis used Kruskall Wallis test and Mann Whitney test with 5\% significance level. The results of organoleptic test showed that the most preferred formula by panelists was F2 with an average value of 3,6 . There are differences in terms of smell characteristic $(p=0.017)$ and taste characterictic $(p=0.021)$. F2 have the highest content of vitamin B12 and folic acid, which are $1.58 \mathrm{mcg}$ and 1,62 mcg, respectively, for 50 gram snack bar. The study showed that the best optimization (acceptability and nutrient content) in formula is F2 (substitution of $20 \%$ of purple sweet potato and addition $9 \mathrm{~g}$ of nutritional yeast). Therefore, snack bar with purple sweet potato substitution and nutritional yeast enrichment is feasible as an alternative healthy snack for vegan.
\end{abstract}

Keywords: folic acid, nutritional yeast, purple sweet potato (Ipomoea Batatas L.), snack bar, vegan, vitamin B12.

\section{INTRODUCTION}

Vegan is a community group that applies dietary pattern of not using or consuming products derived from animals, animal products, and its derivatives (Wirnitzer, 2018). Vegan diet were included as the risk factors for vitamin B12 deficiency (Pawlak et al., 2014). Deficiency of vitamin B12 when combined with folic acid deficiency will cause megaloblastic anemia (Almatsier, 2011). Efforts to overcome megaloblastic anemia are oriented towards preventing deficiencies of both nutrients. Supplementation of vitamin B12 and folic acid has been considered to be the best solution to prevent megaloblastic anemia in vegan society, but in reality it is considered ineffective. This is due to the tendency of the vegan community to adopt or orient towards non-supplement diet, known as clean eating (Cramer et al., 2017). Some vegan groups even apply raw vegan diet (Pawlak et al.,
2014). Therefore, dietary supplementation cannot solve the problem of megaloblastic anemia in vegan society.

An effective solution to prevent megaloblastic anemia in vegan society due to deficiency of vitamin B12 and folic acid is through food formulation. Food formulation can be done by adding certain food ingredients to the food that is commonly consumed by vegan community and does not go against vegan diet. Nutritional yeast can be act as source of vitamin B12 and folic acid, and purple sweet potato (Ipomoea Batatas L.) as a source of fiber and folic acid.

Nutritional yeast is yeast derived from deactivated and dried from Saccharomyces cereviciae bacteria. The nutrient content of nutritional yeast includes carbohydrates, protein, fat, vitamins and minerals. Nutritional yeast also contains several nutrients that are not found in other vegetable sources, that is lysine and 
methionine and several vitamins (Jach \& Serefko, 2018). Nutritional yeast has a taste similar to cheese, which is salty and savory. Because of its common taste, nutritional yeast can be accepted by all people, including vegetarian.

Nutritional yeast has been widely available in market with certain brands, one of which is Bob's Red Mill. 1 gram of nutritional yeast with Bob's Red Mill brand contains 1.17 mcg of vitamin B12 and $121.6 \mathrm{mcg}$ of folic acid. Addition of 1 gram of nutritional yeast in food has met $48.8 \%$ vitamin B12 total requirement and 30.4\% folic acid total requirement according to $2013 \mathrm{RDA}$. This content is sufficient for snack requirements with claims as sources of vitamin B12 and folic acid, which contain $15 \%$ of nutritional adequacy rate (BPOM, 2016).

Purple sweet potato as source of folic acid and fiber can affect the texture of food products, so that these foods are not easily damaged. According to Winarno (2004), fiber and water content in food dough determines texture of food product. In addition to a source of folic acid and fiber, purple sweet potato also contain vitamin, mineral and antioxidant (Restuono et al, 2013). Purple sweet potato contain the highest antioxidant compared to other type of sweet potato, including anthocyanin, phenolic acid (quinic acid and ferulic acid), and flavonoid (O-hexoside of quercetin, chrysoeriol) (Wang et al., 2018). According to Restuono (2017), purple sweet potato can be found throughout Indonesia, one of which is in Pacet District, Mojokerto Regency. Purple sweet potato is one of main commodity in Mojokerto. Purple sweet potato can be processed into flour before it is used in food formulation.

One food formulation alternative that target vegan community is snack bar. Snack bar are included in snack commonly consumed by vegan community. According to Saputro (2018) snack bar is ready-to-eat snack. In general, snack bar are made from ingredient that are rich in nutrients such as various type of nuts, fruit, and other. The main ingredient and other additional ingredient can be mixed using binder and formed into stick that can be cut to desired size.

Snack bar formula refers to commercial snack bar product that is soyjoy variants strawberry and pineapple flavors, with modification adapted to the principle of vegan food. The main ingredient for snack bar are soy flour, sugar, cacao butter, chia seeds, salt and vanilla, and additional ingredients consisted of raisins and pineapple. According to Guiotto and Nancy (2014), chia seed play a role in strengthening nutrition bar and bread structure. Cacao butter as a binder has unsaturated fatty acid up to $40 \%$ and has a better biocompatibility compared to semi-synthetic fats (Kim et al., 2005). Soybean flour can be substituted with purple sweet potato flour aiming to increase fiber and folic acid content, as well as adding nutritional yeast to provide value for vitamin $\mathrm{B} 12$ content and increase the value of folic acid.

This study aims to formulate food in groups of people who are more susceptible to megaloblastic anemia. Fibriafi (2018) conducted research on food formulation in an effort to prevent megaloblastic anemia in ovo-vegetarian community in Surabaya. Sources of vitamin B12 were used seaweed flour and eggs which are used as a composition in making brownies. In contrast to this study, the composition of eggs cannot be used because it is against vegan diet rule, so the sources of vitamin B12 that can be used in this study are more limited and have higher difficulty.

The problem of nutrient deficiency is the background of this study to analyze the acceptability and nutritional content of snack bars substituting purple sweet potato flour enriched with nutritional yeast. The output of this study is the best snack bar formula through formula optimization. In hope that the substitute snack bar for purple sweet potato flour enriched with nutritional yeast can be accepted and provide access to food sources of vitamin B12 as well as an alternative source of folic acid for vegan community.

\section{METHOD}

This research is a true experimental using complete randomized design. This study used 1 snack bar control formula (F0) and 2 snack bar formulas substituting purple sweet potato flour and adding nutritional yeast (F1 and F2). Control formula there were no substitutions and additions, while in modified formula, 10\% (F1) and 20\% (F2) purple sweet potato flour was given, and $6 \mathrm{~g}$ and 9 
g nutritional yeast were added, respectively (Table 1). This research was conducted from December 2018 to March 2019.

The snack bar was made at Nutrition Laboratory, Universitas Airlangga. Organoleptic tests covering color, aroma, texture, and taste on consumer panelists were carried out in vegan community "Yayasan Budha Maitreya" at Jalan Dukuh Kupang Utara 1 No. 2-4, Putat Jaya, Kec. Sawahan, Surabaya. Test for content of vitamin B12 and folic acid was carried out in Nutrition Laboratory, Universitas Airlangga through absorbance reading method using spectrophotometer and Lactobacillus leichmanii ATCC 7830 test organism.

Research sample was snack bar substitution of purple sweet potato flour which was enriched with nutritional yeast using developed formula. Sample size presented to panelists was $10 \mathrm{~g}$ for each snack bar formula. A total of 38 consumer panelists assessed sample presented by filling out questionnaire using scale value of 1 to 5 on each of preference tests (color, aroma, texture, and taste). Assessment of preference test includes: $1=$ very dislikes, $2=$ dislikes, $3=$ neutral, $4=$ likes, and 5 $=$ very likes.

The results of preference test are processed, analyzed, and interpreted to determine formula with the highest acceptance value. The differences of substitution of purple sweet potato flour and addition of nutritional yeast was known after Kruskal Wallis test $\alpha \leq 0.05$, while the differences in each formula were known after Mann Whitney test $\alpha \leq 0.05$. Formula with the highest acceptance value was tested for vitamin B12 and folic acid levels in Nutrition Laboratory. The ingredienta used in making snack bar substitution of purple sweet potato flour which are enriched with nutritional yeast include soy flour, purple sweet potato flour, nutritional yeast, cacao butter, sugar, chia seeds, salt and vanilla, pineapple and raisins. The formulation of snack bar substitution of purple sweet potato flour which is enriched with nutritional yeast is presented in Table 1 .

The process of making snack bar consisted of preparation stage, processing stage, and packaging stage. In preparation stage, soybean flour and purple sweet potato flour are roasted until smells good and are filtered using sieve. This aimed to get
Table 1. Purple sweet potato flour enriched with nutritional yeast Snack Bar Formulation

\begin{tabular}{lrrr}
\hline \multirow{2}{*}{ Ingredients (g) } & \multicolumn{3}{c}{ Formula } \\
\cline { 2 - 4 } & F0 & F1 & F2 \\
\hline Soybean Flour & $\mathbf{1 5 0}$ & $\mathbf{1 3 5}$ & $\mathbf{1 2 0}$ \\
Purple Sweet Potato Flour & $\mathbf{0}$ & $\mathbf{1 5}$ & $\mathbf{3 0}$ \\
Nutritional yeast & $\mathbf{0}$ & $\mathbf{6}$ & $\mathbf{9}$ \\
Cacao butter & 50 & 50 & 50 \\
Sugar & 50 & 50 & 50 \\
Raisin & 10 & 10 & 10 \\
Pineapple & 10 & 10 & 10 \\
Chia seed & 10 & 10 & 10 \\
Vanilla & 4 & 4 & 4 \\
Salt & 4 & 4 & 4 \\
Total & $\mathbf{2 8 8}$ & $\mathbf{2 9 4}$ & $\mathbf{2 9 7}$ \\
\hline
\end{tabular}

Information

F0: soy flour $=150 \mathrm{~g}$; purple sweet potato flour $=0 \mathrm{~g}$; Nutritional yeast $=0 \mathrm{~g}$

$\mathrm{F} 1$ : soy flour $=135 \mathrm{~g}$; purple sweet potato flour $=15 \mathrm{~g}$; nutritional yeast $=6 \mathrm{~g}$

F2: soy flour $=120 \mathrm{~g}$; purple sweet potato flour $=30 \mathrm{~g}$; Nutritional yeast $=9 \mathrm{~g}$

the smallest and even flour particle. Next process is to soak chia seeds and raisins for 10 minute, and chop filling ingredients (pineapple and raisin).

The processing process is carried out by mixing all ingredients, except stuffing ingredients, into food processor until all ingredients are evenly mixed. The stuffing ingredients are mixed in the dough before it is printed on baking sheet. The dough is molded with a thickness of $1.5 \mathrm{~cm}$ and baked in oven at $150^{\circ} \mathrm{C}$ for 75 minute. In the last 10 minute, snack bar was given nutritional yeast on top (as topping). The snack bar is removed from the oven and cooled to room temperature.

The packaging stage is carried out by packing the snack bar with aluminum foil and closed using hot press sealer. Next snack bar was given to the panelists for organoleptic testing. This research has been approved by the Health Research Ethics Commission, Faculty of Dentistry, Universitas Airlangga number 032/HRECC.FODM/II/2019.

\section{RESULT AND DISSCUSION}

Organoleptic test results by consumer panelists on color preference for snack bar are presented in Table 2. The highest color preference is F2. The color of control snack bar is brownish yellow, while modified snack bar is brown. Consumer 
panelists like the three types of snack bar color. The average assessment of consumer panelists on the color of snack bar F0 and F1 has the same value, while the assessment of color preference on snack bar F2 has increased. This is in line with research on manufacture of black soybean sweet potato snack bars. In Avianty research (2013) in manufacture of black soybean sweet potato snack bar, panelist like control and modification snack bars and there is no significant differences.

The brownish color produced from control and modified snack bars is the result of mailard reaction between lysine found in soybean and reducing sugar. Lysine has 2 amine groups which react with reducing sugar to produce a dark or dark brown color (Dewi, 2006). The darker color of modified snack bar than control was the result of a combination of purple sweet potato flour and soybean flour.

Organoleptic test results by consumer panelists on the level of preference for the aroma of snack bar are presented in Table 3. The highest level of preference for aroma is F2. The aroma in control snack bar was dominated by aroma of soy flour, cacao butter, and vanilla, while modified snack bar was dominated by aroma of soy flour, cacao butter, purple sweet potato flour, and vanilla.

Purple sweet potato gives a distinctive aroma to the modified snack bar. The aroma increases panelist's preference to snack bar. There is no unpleasant aroma that has potential to cause panelists to dislike it. This is because lipoxygenase enzyme has been lost in roasting process. Heating process functions to deactivate the lipoxygenase enzyme in these two ingredients (Dewi, 2006).

Consumer panelists like the aroma of snack bar F2 the most with the highest average, after that followed by the average consumer assessment of snack bar F0, then snack bar F1. This is in line with Avianty (2013) on the manufacture of black soybean sweet potato snack bars, the aroma of snack bars with purple sweet potatoes increases panelist's preference for the aroma of snack bar.

The results of organoleptic test by consumer panelists on preference for snack bar texture are presented in Table 4. The highest level of texture preference is F2. The texture of modified and control snack bar is the same, which is slightly hard. Consumer panelists like the three types of snack bar texture. The average consumer panelist assessment of snack bar F0 texture has the lowest value, while the texture of snack bar F1 and F2 has the same value. This is in line with Avianty (2013) on the manufacture of black soybean sweet potato snack bars, which is the texture of purple sweet potato snack bar did not increase panelist's preference for the texture of snack bar.

In snack bar with purple sweet potato substitution which is enriched with nutritional

Table 2. Distribution of Panelist's Preference to Snack Bar Color

\begin{tabular}{|c|c|c|c|c|c|c|c|c|c|c|c|c|c|c|}
\hline \multirow{3}{*}{ Code } & \multicolumn{10}{|c|}{ Preference Scale } & \multirow{2}{*}{\multicolumn{2}{|c|}{ Total }} & \multirow{3}{*}{$\begin{array}{l}\text { Total } \\
\text { Score }\end{array}$} & \multirow{3}{*}{ Mean } \\
\hline & \multicolumn{2}{|c|}{1} & \multicolumn{2}{|c|}{2} & \multicolumn{2}{|c|}{3} & \multicolumn{2}{|c|}{4} & \multicolumn{2}{|c|}{5} & & & & \\
\hline & $\mathbf{n}$ & $\%$ & $\mathbf{n}$ & $\%$ & $\mathbf{n}$ & $\%$ & $\mathbf{n}$ & $\%$ & $\mathbf{n}$ & $\%$ & $\mathbf{n}$ & $\%$ & & \\
\hline F0 & 0 & 0 & 3 & 7.9 & 24 & 63.2 & 6 & 15.8 & 5 & 13.2 & 38 & 100 & 127 & 3.34 \\
\hline $\mathrm{F} 1$ & 0 & 0 & 2 & 5.3 & 22 & 57.9 & 13 & 34.2 & 1 & 2.6 & 38 & 100 & 127 & 3.34 \\
\hline $\mathrm{F} 2$ & 0 & 0 & 2 & 5.3 & 19 & 50.0 & 14 & 36.8 & 3 & 7.9 & 38 & 100 & 132 & 3.47 \\
\hline
\end{tabular}

Note : $1=$ very dislike; $2=$ dislike; $3=$ neutral; $4=$ like; $5=$ very like.

Table 3. Distribution of Panelist's Preference to the Snack Bar Aroma

\begin{tabular}{|c|c|c|c|c|c|c|c|c|c|c|c|c|c|c|}
\hline \multirow{3}{*}{ Code } & \multicolumn{10}{|c|}{ Preference Scale } & \multirow{2}{*}{\multicolumn{2}{|c|}{ Total }} & \multirow{3}{*}{$\begin{array}{l}\text { Total } \\
\text { Score }\end{array}$} & \multirow{3}{*}{ Mean } \\
\hline & \multicolumn{2}{|c|}{1} & \multicolumn{2}{|c|}{2} & \multicolumn{2}{|c|}{3} & \multicolumn{2}{|c|}{4} & \multicolumn{2}{|c|}{5} & & & & \\
\hline & $\mathbf{n}$ & $\%$ & $\mathbf{n}$ & $\%$ & $\mathbf{n}$ & $\%$ & n & $\%$ & $\mathbf{n}$ & $\%$ & $\mathbf{n}$ & $\%$ & & \\
\hline F0 & 0 & 0 & 4 & 10.5 & 17 & 44.7 & 14 & 36.8 & 3 & 7.9 & 38 & 100 & 130 & 3.42 \\
\hline $\mathrm{F} 1$ & 1 & 2.6 & 6 & 15.8 & 19 & 50.0 & 8 & 21.1 & 4 & 10.5 & 38 & 100 & 129 & 3.21 \\
\hline $\mathrm{F} 2$ & 0 & 0 & 3 & 7.9 & 9 & 23.7 & 21 & 55.3 & 5 & 13.2 & 38 & 100 & 135 & 3.74 \\
\hline
\end{tabular}

Note : $1=$ very dislike; $2=$ dislike; $3=$ neutral; $4=$ like; $5=$ very like. 
Table 4. Distribution of Panelist's Preference to the Snack Bar Texture

\begin{tabular}{|c|c|c|c|c|c|c|c|c|c|c|c|c|c|c|}
\hline \multirow{3}{*}{ Code } & \multicolumn{10}{|c|}{ Preference Scale } & \multirow{2}{*}{\multicolumn{2}{|c|}{ Total }} & \multirow{3}{*}{$\begin{array}{l}\text { Total } \\
\text { Score }\end{array}$} & \multirow{3}{*}{ Mean } \\
\hline & \multicolumn{2}{|c|}{1} & \multicolumn{2}{|c|}{2} & \multicolumn{2}{|c|}{3} & \multicolumn{2}{|c|}{4} & \multicolumn{2}{|c|}{5} & & & & \\
\hline & $\mathbf{n}$ & $\%$ & $\mathbf{n}$ & $\%$ & $\mathbf{n}$ & $\%$ & $\mathbf{n}$ & $\%$ & $\mathbf{n}$ & $\%$ & $\mathbf{n}$ & $\%$ & & \\
\hline F0 & 0 & 0 & 5 & 13.2 & 20 & 50.6 & 9 & 23.7 & 4 & 10.5 & 38 & 100 & 126 & 3.32 \\
\hline F1 & 0 & 0 & 4 & 10.5 & 15 & 39.5 & 14 & 36.8 & 5 & 13.2 & 38 & 100 & 134 & 3.53 \\
\hline $\mathrm{F} 2$ & 0 & 0 & 3 & 7.9 & 16 & 42.1 & 15 & 39.5 & 4 & 10.5 & 38 & 100 & 134 & 3.53 \\
\hline
\end{tabular}

Note : $1=$ very dislike; $2=$ dislike; $3=$ neutral; $4=$ like; $5=$ very like.

yeast, the texture is influenced by purple sweet potato, water, chia seeds, sugar, and cacao butter.

Sugar, chia seeds, and cacao butter act as binder for snack bar and make snack bar texture solid. Fiber from purple sweet potato flour and water mixed with chia seeds affects the structure of modified snack bar. According to Winarno (2004), fiber and water levels in food play a major role in influencing texture of food.

Organoleptic test results by consumer panelists on the level of taste preference for snack bars are presented in Table 5. The highest level of taste preference is F2. Each formula, both controlled and modified, is added with cacao butter, sugar and salt to enhance the taste of snack bar. The taste of control snack bar was dominated by savory taste of soybean flour, while modified snack bar was dominated by combination of savory flavors of soybean flour and sweet which was typical of purple sweet potato flour.

The taste of purple sweet potato gives a distinctive taste to modified snack bar, thereby increasing panelist's preference for the taste of modified snack bar. This is in line with Avianty (2013) on manufacture of black soybean sweet potato snack bars which also states that the use of purple sweet potatoes in snack bar increase panelist's preference for taste. The sweet taste of modified snack bar comes from sugar and natural sugars in purple sweet potatoes, which is maltose, sucrose, fructose and glucose (Anggita, 2008).
Each formula has a different amount of soy flour, purple sweet potato flour, and nutritional yeast, so it affects the characteristics of snack bar. The results of statistical analysis with Kruskal Wallis showed a significant difference $(p \leq 0.05)$ in aroma and taste characteristic.

Through Mann-Whitney test, there is a significant difference in aroma characteristics of F1 snack bar with aroma of F2 snack bar, but there is no significant difference between aroma of snack bar F0 and aroma of modified snack bar formula. This also happen to taste characteristic of snack bar. There is a significant difference in taste characteristics of F1 snack bar and taste of F2 snack bar, but there is no significant difference between taste of F0 snack bar and modified snack bar formula.

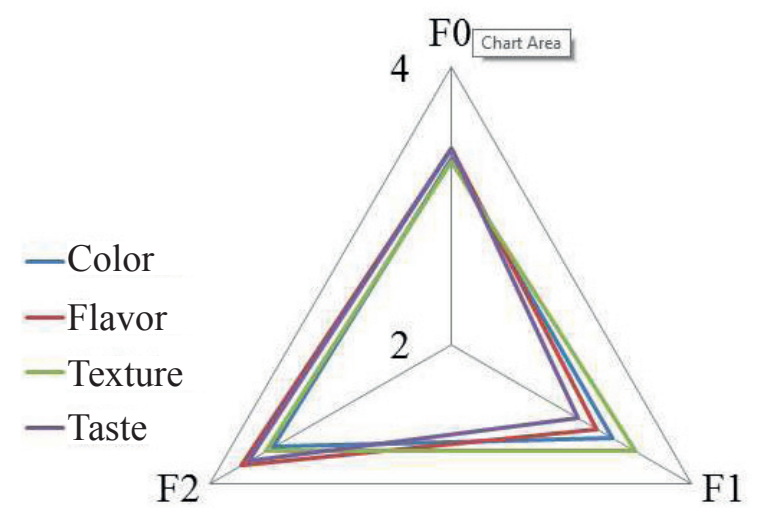

Figure 1. Overall Snack Bar Acceptance Assessment Diagram

Table 5. Distribution of Panelist's Preference to the Snack Bar Taste

\begin{tabular}{|c|c|c|c|c|c|c|c|c|c|c|c|c|c|c|}
\hline \multirow{3}{*}{ Code } & \multicolumn{10}{|c|}{ Preference Scale } & \multirow{2}{*}{\multicolumn{2}{|c|}{ Total }} & \multirow{3}{*}{$\begin{array}{l}\text { Total } \\
\text { Score }\end{array}$} & \multirow{3}{*}{ Mean } \\
\hline & \multicolumn{2}{|c|}{1} & \multicolumn{2}{|c|}{2} & \multicolumn{2}{|c|}{3} & \multicolumn{2}{|c|}{4} & \multicolumn{2}{|c|}{5} & & & & \\
\hline & n & $\%$ & $\mathrm{n}$ & $\%$ & $\mathrm{n}$ & $\%$ & $\mathrm{n}$ & $\%$ & n & $\%$ & $n$ & $\%$ & & \\
\hline F0 & 0 & 0 & 4 & 10.5 & 20 & 52.6 & 8 & 21.1 & 6 & 15.8 & 38 & 100 & 130 & 3.42 \\
\hline $\mathrm{F} 1$ & 1 & 2.6 & 12 & 31.6 & 12 & 31.6 & 10 & 26.3 & 3 & 7.9 & 38 & 100 & 122 & 3.05 \\
\hline $\mathrm{F} 2$ & 0 & 0 & 3 & 7.9 & 14 & 36.8 & 13 & 34.2 & 8 & 21.1 & 38 & 100 & 134 & 3.68 \\
\hline
\end{tabular}

Note : 1 = very dislike; 2 = dislike; $3=$ neutral; $4=$ like; $5=$ very like. 
Table 6. The value of the content of vitamin B12 and folic acid in a snack bar in a serving dose of 50 grams

\begin{tabular}{lccccc}
\hline \multicolumn{1}{c}{ Nutrient } & RDA* & $\begin{array}{c}\text { Vitamin Sources } \\
\text { Snack Rule }\end{array}$ & $\begin{array}{c}\text { Nutrient per } \\
\text { Serving }\end{array}$ & $\begin{array}{c}\text { RDA } \\
\text { Contribution (\%) }\end{array}$ & Comercial Product Content ** \\
\hline Vitamin B12 (mcg) & 2.4 & $15 \%$ & 1.58 & $65.8 \%$ & unknown \\
Folic Acid (mcg) & 400 & $15 \%$ & 1.62 & $0.41 \%$ & 80 \\
\hline
\end{tabular}

Note: * The nutritional adequacy of men and women aged 10 to 60 years

** Product snack bar "Soyjoy" Strawberry flavor variant

The $10-20 \%$ substitution of ingredients resulted in significant differences in characteristic, especially purple sweet potato flour affected preference of panelists in snack bar. Snack bar F2 as the control formula has the highest assessment of all characteristics of preference test assessment. Another indicator to be an alternative snack source of vitamin B12 and folic acid is that it contains $15 \%$ of the nutritional adequacy rate. Nutritional values based on calculations and laboratory results are presented in Table 6.

Table 6 shows the results of calculation of vitamin B12 and folic acid value per 50 gram of snack bar. Vitamin B12 snack bar on DKBM calculation $(1.8 \mathrm{mcg})$ shows a higher amount than laboratory results $(1.58 \mathrm{mcg})$, while snack bar folic acid has a high range of differences between DKBM calculations and laboratory results. The results of folic acid calculation using DKBM $(108.4 \mathrm{mcg})$ showed a higher amount than laboratory results $(1.62 \mathrm{mcg})$. The amount of vitamin B12 snack bar substitution of purple sweet potato which is enriched with nutritional yeast has fulfilled the regulation of the Head of BPOM RI No. 13 of 2016, which fulfills $15 \%$ of total nutritional adequacy based on 2013 RDA. Snack bar's folic acid content has a low amount, so it does not meet minimum amount in the regulation.

The significant difference in folic acid content between the results of calculations based on DKBM and laboratory results was due to the use of terminology in calculations based on DKBM, which is purple sweet potato. The process of collecting purple sweet potatoes reduces content of folic acid to a minimum amount because folic acid is susceptible to damage in heat-dry process (Miftakhussolikhah et al., 2015). Heating process causes significant damage to folic acid A heating temperature of $120^{\circ} \mathrm{C}$ for 22 minutes has reduced folic acid level by $80 \%$ (Qodriah, 2016), while vitamin B12 is relatively stable in hot, aerobic, and slightly acidic condition (Almatsier, 2011). The appropriate method for processing folic acid source material is by blanching at a temperature of $100^{\circ} \mathrm{C}$ in less than 15 minute (Miftakhussolikhah et al., 2015).

Formula optimasi dihitung berdasarkan pembobotan daya terima (warna, aroma, tekstur, rasa, dan preferensi) dan nilai kandungan gizi (vitamin B12 dan asam folat). Formula optimasi dengan bobot tertinggi adalah F2, sesuai dengan tujuan formulasi makanan yaitu membuat produk makanan dengan daya terima yang layak dan nilai gizi yang cukup. Snack bar F2 merupakan formula dengan substitusi ubi ungu dan penambahan nutritional yeast yang tepat.

Optimization formula is calculated based on weighting of acceptability (color, aroma, texture, taste, and preference) and nutritional value (vitamin B12 and folic acid). The optimization formula with the highest weight is F2, in accordance with the purpose of food formulation, which make food product with adequate acceptance and sufficient nutritional value. Snack bar F2 is a formula with substitution of purple sweet potato and the right addition of nutritional yeast.

\section{CONCLUSION}

Substitution of purple sweet potato and addition of nutritional yeast had a significant effect on acceptability and nutritional content (vitamin B12 and folic acid) of snack bar. Based on results of optimization formula analysis, it was concluded that F2 snack bar had the best acceptance with the highest value of vitamin B12 and folic acid. F2 snack bar formula is suitable as an alternative healthy snack for the choice of vitamin B12 sources as a result of substituting purple sweet potato and adding nutritional yeast.

Purple sweet potato substitution snack bars and nutritional yeast additions can be a healthy 
snack alternative for vegan community with the recommended serving size of 50 grams to meet the needs of $65.8 \%$ RDA for vitamin B12. In addition, to increase folic acid intake, vegan are advised to maintain consumption of green vegetables such as broccoli, kale, spinach, and others, as well as fruits to get enough folic acid intake.

\section{REFERENCES}

Almatsier, S. (2011). Prinsip Dasar Ilmu Gizi. Jakarta: PT. Gramedia Pustaka Utama.

Avianty, S. (2013). Kandungan zat gizi dan tingkat kesukaan snack bar ubi jalar kedelai hitam sebagai alternatif makanan selingan penderita diabetes mellitus tipe 2. Skripsi. Universitas Diponegoro.

Badan Pengawasan Obat dan Makanan. (2016). Peraturan Kepala BPOM RI No. 13. Jakarta: Badan Pengawasan Obat dan Makanan RI.

Cramer, H., Kessler, C.S., Sundberg, T., Leach, M.J., Schumann, D., Adams, J., \& Lauche, R. (2017). Characteristics of americans choosing vegetarian and vegan diets for health reasons. Journal of Nutrition Education and Behavior, 49(7), 561-567.e1. doi: 10.1016/j. jneb.2017.04.011.

Dewi, P.K. (2006). Pengaruh lama fermentasi dan suhu pengeringan terhadap jumlah asam amino lisin dan karakter fisiko kimia tepung tempe. Skripsi. Semarang: Universitas Katolik Soegijapranata Semarang.

Fibriafi, R. (2018). Pengaruh substitusi tepung kedelai, tepung bekatul dan tepung rumput laut (gracilaria $s p$ ) terhadap daya terima, nilai gizi, dan nilai ekonomi bownies bar sebagai snack alternatif untuk mencegah anemia pada wus ovo vegetarian. Media Gizi Indonesia: Vol 13, No 1. doi: 10.20473/mgi.v13i1.12-19

Guiotto, N.E. \& Nancy, E. (2014). Aplicación de subproductos de Chía (Salvia hispanica L.) y Girasol (Helianthus annus L.) en alimentos. Thesis. University Buenos Aires, Argentina. Retrieved from http://sedici.unlp.edu.ar/ handle/10915/34268.
Jach, M.E., \& Serefko, A. (2018). Chapter 9 Nutritional Yeast Biomass: Characterization and Application. Diet, Microbiome and Health. Elsevier Inc. doi: 10.1016/B978-0-12-8114407.00009-0.

Kim, B., Na, K., \& Choi, H. (2005). Preparation and characterization of solid lipid nanoparticles ( SLN ) made of cacao butter and curdlan. European Journal of Pharmaceutical Science 24, 199-205. doi: 10.1016/j.ejps.2004.10.008.

Miftakhussolikhah, Kurniadi, M., Poeloengasih, C.D., Frediansyah, a., \& susanto, a. (2015). folate content of mung bean flour prepared by various heat- treatments. Italian Oral Surgery, 3, 69-73. doi: 10.1016/j.profoo.2015.01.006.

Pawlak, R., Lester, S.E., \& Babatunde, T. (2014). The prevalence of cobalamin deficiency among vegetarians assessed by serum vitamin B12: A review of literature. European Journal of Clinical Nutrition, 68(5), 541-548. doi: 10.1038/ejen.2014.46.

Qodriah, F.L. (2016). Stabilitas zat gizi mikro (Asam Folat dan Fe Fumarat) pada Produk Banana Flakes Fortifikasi Selama Proses Pengolahan. Skripsi. Universitas Pasundan.

Restuono, J. (2017). Penampilan hasil dan karakter agronomis ubi jalar ungu. Prosiding Seminar Hasil Penelitian Tanaman Aneka Kacang Dan Umbi, 608-618.

Saputro, R.B.A. (2018). Pengaruh substitusi tepung ampas tahu (glycine max) dan penambahan pisang ambon (musa acuminata) terhadap nilai organoleptik, nilai gizi, dan nilai ekonomi snack bar tinggi kalium dan serat sebagai alternatif makanan selingan atlet. Jurnal Kedokteran Brawijaya: 29 (1) 21-29.

Wang, A., Li, R., Ren, L., Gao, X., Zhang, Y., Ma, Z., $\&$ Ma, D. (2018). A comparative metabolomics study of $\mathrm{fl}$ avonoids in sweet potato with di ff erent fl esh colors (Ipomoea batatas (L.) Lam). Food Chemistry, 260(March), 124-134. doi: 10.1016/j.foodchem.2018.03.125.

Winarno, F.G. (2004). Kimia Pangan dan Gizi. Jakarta: PT Gramedia Pustaka Utama.

Wirnitzer, K.C. (2018). Vegan nutrition: latest boom in health and exercise. therapeutic, probiotic, and unconventional foods. Elsevier Inc. doi: /10.1016/B978-0-12-814625-5.00020-0. 